\title{
The Implementation of the Strict-Liability Principle to the Perpetrators of Forest and Land Burning
}

\author{
Hafrida $^{*}$, Helmi $^{* *}$, Bunga Permatasari ${ }^{* * *}$ \\ DOI: https://doi.org/10.22304/pjih.v7n3.a2
}

Submitted: September 1, 2020 | Accepted: November 21, 2020

\begin{abstract}
The massive forest and land fires in Indonesia have been raging and caused haze disaster. The haze disaster is not suffered only in Indonesian territory, but it has become a transnational disaster resulting in extensive economic and health quality losses. In addition, the disaster has led damage to agricultural land and disruption of diplomatic relations among affected states. The number of perpetrators of forest and land fires that increase annually shows that the enforcement of criminal law is relatively ineffective. This article covers the problem whether the principle of strict liability can be applied to the perpetrators of forest burning. In 2019, forest fires in the Jambi Province had took placed in estimated 165.86 .58 hectares. The forest fire is the main source of transnational haze disaster. Law enforcement on forest fires in Jambi has not provided a deterrent effect yet. There are forty-six companies acquiring fires in their concession land areas. Unfortunately, only four of them reached court proceedings and only two companies were declared guilty by the court. Therefore, as a deterrent effort, the principle of strict liability can be applied as the main principle to handle perpetrators of forest burning.
\end{abstract}

Keywords: criminal law enforcement, forest fires, strict liability.

\section{Penerapan Asas Strict Liability (Tanggung Jawab Mutlak) terhadap Pidana Pelaku Tindak Pidana Membakar Hutan dan Lahan}

\begin{abstract}
Abstrak
Tingginya tingkat kebakaran hutan dan lahan yang berdampak pada bencana kabut asap, tidak hanya berdampak di wilayah Indonesia tetapi juga menjadi bencana lintas negara serta mengakibatkan kerugian yang luas, termasuk kerugian ekonomi dan kerugian akan mutu kesehatan, rusaknya lahan pertanian serta berakibat pada terganggunya hubungan diplomatik antar negara yang turut serta terdampak. Melihat pada banyaknya pelaku pembakaran hutan dan lahan yang berulang setiap tahunnya menunjukan bahwa penegakan hukum pidana melalui pemidanaan pelaku tidak efektif. Maka permasalahan dalam artikel ini adalah apakah asas strict liability ini dapat diterapkan dalam

PADJADJARAN Journal of Law Vol. 7 Number 3 Year 2020 [ISSN 2460-1543] [ISSN 2442-9325]

* Lecturer of the Department of Criminal Law, the Faculty of Law, Universitas Jambi, Jl. Jambi-Ma. Bulian Km. 15 Mendalo Indah Jambi, Dr., S.H., M.H. (Universitas Jambi), hafrida_hukum@unja.ac.id

** Lecturer of the Department of State Administration Law, the Faculty of Law, Universitas Jambi, Jl. Jambi-Ma. Bulian Km. 15 Mendalo Indah Jambi, Dr., S.H., M.H. (Universitas Jambi), helmi@unja.ac.id

*** Lecturer of the Department of State Administration Law, the Faculty of Law, Universitas Jambi, Fakultas Hukum Universitas Jambi, Jl. Jambi-Ma. Bulian Km. 15 Mendalo Indah Jambi, S.H., M.H. (Universitas Jambi), bungapermatasari@unja.ac.id
\end{abstract}


pertanggungjawaban pidana pelaku tindak pidana pembakaran hutan dan lahan sebagai upaya penjeraan pada pelaku? Kondisi empirik kebakaran hutan di Jambi pada tahun 2019 memperlihatkan luas wilayah yang terbakar mencapai 165.86 .58 hektare yang merupakan sumber penyebab utama bencana asap lintas negara. Penegakan hukum atas bencana kebakaran hutan dan lahan di Provinsi Jambi belum memberikan efek jera, dari 46 (empat puluh enam) Perusahaan yang mengalami kebakaran di wilayah konsesinya, hanya 4 (empat) perusahaan yang perkaranya sampai pada proses peradilan dan dari 4 (empat) perusahaan tersebut hanya 2 (dua) perusahaan yang dinyatakan bersalah oleh pengadilan. Untuk itu ke depan sebagai upaya penjeraan sudah seharusnya diterapkan asas strict liability sebagai asas utama dalam pertanggungjawaban pidana pelaku pembakaran hutan dan lahan.

Kata kunci: kebakaran hutan dan lahan, penegakan hukum pidana, tanggung jawab mutlak.

\section{A. Introduction}

Uncontrolled forest fires lead to a wide and systemic impact, starting from causing poor air quality due to smoke and harmful particles, public health decrease, environmental damage, and ultimately ecosystem destruction. The government and local governments have made various efforts to manage the disaster. The increasingly serious condition of forest and land fires requires serious treatment, including seriousness in upholding forest and land fire laws. For that purpose, the enforcement of criminal law through the implementation of the principle of strict liability can be considered an alternative.

Absolute criminal responsibility is different from general criminal responsibility. In general, criminal responsibility requires the existence of a fault, known as a liability based on fault. Fault in criminal responsibility can be in the form of deliberate action and negligence. If there is no element of wrongdoing in a criminal act, whether it is intentional or negligent, the perpetrator of the criminal act cannot be considered criminally responsible. In addition to the principle of geen straf zonder schuld, there is a principle of strict liability where criminal responsibility does not depend on a fault.

According to Schwartzbach, strict liability is a concept of criminal responsibility for perpetrator of criminal offense in which public prosecutor or judge applies decision without the need to prove that the defendant intended or did not commit a criminal act. The public prosecutor does not even need to prove whether the defendant committed the act because of negligence.

"In criminal law, strict liability laws punish people regardless of their state of mind - the prosecution doesn't need to prove that a defendant intended to do something that's illegal. The prosecution doesn't even need to establish that the defendant was reckless or negligent ${ }^{\prime \prime}{ }^{1}$

Micah Schwartzbach, "Is There "Strict Liability" in Criminal Law?", https://www.nolo.com/legalencyclopedia/is-strict-liability-criminal-law.html, accessed on June 2020. 
Hitherto, strict liability is often used in the realm of civil law, especially in terms of accountability through providing compensation for losses. Article 88 of the Law Number 32 of 2009 on Environmental Protection and Management (Environmental Law) mention that every person whose actions, business, and/or activities using hazardous and toxic materials, producing and/or managing waste of hazardous and toxic materials, and/or posing a serious threat to the environment, is absolutely responsible for the losses incurred as long as the loss is caused by the person concerned. $^{2}$

In the case of liability for the said compensation, plaintiff no longer needs to prove that defendant had committed a careless act causing an incident detrimental to the plaintiff. For example, in a pet bite case, it is no longer necessary to prove how careless the owner of the animal is, it is enough to prove that the defendant's pet bit the defendant.

"Strict liability is a concept mainly applicable to civil, rather than criminal, law. It is a way of holding someone accountable for behavior regardless of fault. It often arises with lawsuits against product manufacturers in applicable cases; the plaintiff does not need to show that the manufacturer was negligent in creating the product. All the plaintiff must show is that the manufacturer is responsible for a defective product and that the defect injured the plaintiff."3

The explanation part of Article 88 of the Law on Environmental Protection and Management states that strict liability requires plaintiff to prove the "guilt" of perpetrator. Therefore, the element of fault is not a legal basis in compensation for losses. In practice, absolute responsibility can be applied in the event of an act that causes serious environmental pollution. The principle of strict liability can be applied only in the case of payment of compensation for civil claims due to damages to the injured party.

The principle of strict liability in criminal cases becomes an interesting issue. The question is whether absolute responsibility can be applied in criminal cases, especially in cases of forest and land fires. The principle of strict liability in the prevention of forest and land fires, especially those committed by corporations, is important because criminal acts of forest and land fires committed by corporations can result in disasters that destroy ecosystems, disrupt public health, and cause losses to the State.

One of the biggest disasters because of forest and land fires is the smoke pollution disaster. It is a serious problem in Indonesia in the last decade. One of the significant events is forest and land fires in Jambi Province, which have contributed

Article 88 Law Number 32 of 2009 on Environmental Protection and Management (Environmental Law). Ibid. 
greatly to the haze disaster. The haze disaster has a wide impact covering not only on economic losses but also on the quality of health, agriculture, and diplomatic relations among affected states.

Due to the negative impacts and losses, the government then banned land clearing by burning. Article 69 paragraph (1) of the Environmental Law prohibits everyone clearing land by burning. Acts as regulated in this article are punishable by serious imprisonment, namely a criminal sanction of at least three (and a maximum of ten) years imprisonment and subject to a minimum fine of three billion and a maximum of ten billion Rupiahs. ${ }^{4}$

Forest and land fires in Jambi Province are a serious problem. The forest fire incident in Jambi can be seen from the results of studies and analysis of Forest and Land Fires in 2019. According to some studies, the burned area covered 165.86.58 hectares, consisting of $114,900.2$ hectares the peat area and 50,286.38 acres nonpeat areas. ${ }^{5}$ Forest fire conditions have reached serious stage and required handling, including serious law enforcement. One of the law enforcement activities is criminal law enforcement by processing forest fires through a judicial process.

Law enforcement on forest fires in Jambi has not provided a deterrent effect yet. There are forty-six companies acquiring fires in their concession land areas. Unfortunately, only four of them reached court proceedings and only two companies were declared guilty by the court. In addition, there are forty people declared suspects.

The problem of criminal law enforcement in law and land fire cases mainly covers the criminal liability that can be applied to perpetrators of forest and land fires. The law enforcement is not only through court but there are other alternatives, such as land sealing by seven companies associated with forest fires. The Director General of Law Enforcement of the Ministry of Forestry and Environment (KLHK) carried out the sealing.

The issue that arises in the case of criminal law enforcement in cases of forest and land fires is the implementation of strict liability to perpetrators of forest and land burnings. Strict liability is a form of responsibility of criminal-act perpetrator. It is carried out immediately without seeing/judging the element of "fault". This absolute responsibility is the exclusion principle from the general principle of criminal liability, namely the principle of geen straft zonder schuld (no crime without fault). Criminal liability, based on this principle of guilt, shows that no one can be convicted before it is proven that there is an element of guilt. In a common crime, "fault" is the basis of accountability. Law Number 41 of 1999 on Forestry (Forestry Law) states that right or permit holders are responsible for forest fires in

\footnotetext{
Articles 69, 108 of the Environmental Law.

Detik News, "Aktivis Nilai Penegakan Hukum Pembakar Hutan di Jambi Tebang Pilih", https://news.detik.com/berita/d-4707982/aktivis-nilai-penegakan-hukum-pembakar-hutan-di-jambi-tebangpilih, accessed on February 2020.
} 
their working areas. ${ }^{6}$ The provisions of this article constitute a basis for the implementation of the principle of strict liability for the cases of forest and land burnings.

\section{B. Theoretical Study of Immediate Criminal Liability (Strict Liability)}

Criminal liability is a logical consequence of crime act. Criminal liability is a process regulated in criminal law. It is a reaction to a criminal act committed by a person, or a form of sanction applied to that person. The formulation of sanctions stipulated in the laws and regulations of the criminal law is a reflection that the act is an act that is rejected by society and, through statutory regulations, the act is declared a disgraceful act. The actor of despicable act will also be criticized through the form of sanctions.

Criminal responsibility does not merely mean imposing punishment on the perpetrator of a criminal act. It also considers the need for such punishment by taking into account the aspect of justice. This means balance between suitability of act and imposed sanction. The formulation of criminal sanctions is formulated negatively. It means that laws and regulations contain or regulate various conditions or situation that the perpetrator cannot account for the committed act (strafuits/uitinggronden). In some states, general reasons for the elimination of criminal liability are regulated.

Imposition of punishment (strafvoraussetzungen) requires prosecutor to prove the existence of a criminal act and it is still necessary to prove the fault of the actor. $^{7}$ Therefore, the imposition of criminal offense against perpetrator of a criminal act requires to prove committed act and the perpetrator's fault. The perpetrator's fault can be in the form of negligence or deliberate action. The absence of fault will result in no accountability for the criminal act committed. In the understanding of this general principle of criminal responsibility, a person who has committed a criminal act even though all the elements of the offense have been fulfilled does not yet fulfill the requirements to be held criminally responsible to that person. In order to be convicted, perpetrator must meet the requirement of offender's fault. This is known as the general principle of being criminally responsible based on the fault of perpetrator.

The principle of strict liability is an exception to the general principle of liability base on fault. In strict liability, there is no need to pay attention to the terms of "fault". When perpetrator of an act prohibited by statutory regulations and the act is in accordance with the conditions/elements of act prohibited by law, the perpetrator has met the requirements to be held accountable.

Because this strict liability is an exception to the general principle of liability based on fault, its implementation is limited to certain actions. An example in

See article 49 of Law Number 41 of 1999 on Forestry (Forestry Law).

Moeljatno, Perbuatan Pidana dan Pertanggungjawaban dalam Hukum Pidana, Jakarta: Bina Aksara, 1985, pp. 22-23. 
Indonesian criminal law is the case of traffic violations. Saleh states that in the case of a violation, there is no need for an assessment of fault. An act of violation is an act in which the level of fault or the inner attitude of the actor is not too serious. Therefore, in adjudicating a case of violation, judge does not require a study or examination of whether there is a fault by the actor. Judge should pay enough attention to whether the defendant has legally and convincingly fulfilled the elements of the act as violated by the law. From the evidences of the elements of the violation, judge can decide whether to give/impose criminal sanctions or not. This is known as the teaching of material deeds, which no longer need to consider whether or not there is an element of fault as a condition for whether or not actor can be convicted. ${ }^{8}$

Strict liability is not a common thing except in the case of violations, especially in traffic violations because the principle of strict liability is an exception from the general principle of criminal responsibility on condition that there is a fault. Without fault, perpetrator will not be criminally responsible. As an exception to this general principle, its implementation is selective and has to meet certain requirements and criteria.

Forest and land burnings in Indonesia can occur due to natural factors such as prolonged dry seasons and human behavior. Some farmers clear concessions or private land by burning land or forests. The combination of natural conditions with long drought caused by El Nino and natural conditions is one of the dominant factors in the occurrence of widespread forest and land fires in Indonesia. Uncontrolled forest and land fires result in serious environmental disasters, such as haze disaster, which has tremendous negative impacts.

CIFOR Research Institute reveals the fact that processing land areas using the mechanism of burning land and forests is a powerful way to gain profits. The advantages of managing the area in clearing land by burning the land are spread as follows in several streams to several parties, both to local elites, national and local authorities as well as plantation developers (reaching 85\%). The remaining profit from the clearing of the land area, $15 \%$ of which is spread among other parties, such as the community demanding their land area, the parties who are assigned as land brokers, the lumberjack workers trees, wood cutters and parties who burn forests and land areas as well as oil palm farmers. ${ }^{9}$ This condition shows that the easiest and cheapest way to clear land is through burning the forest and land. This then triggers the implementation of the principle of strict liability in the enforcement of environmental criminal law.

Roeslan Saleh, Pikiran-Pikiran tentang Pertanggungjawaban Pidana, Jakarta: Ghalia Indonesia, 1982, p. 86.

Glauber (et.al), "Indonesia's Sustainable Landscape Knowledge Report: Losses from Forest Fires \& Analysis of the Economic Impact of the 2015 Fire Crisis", The World Bank, 2016, p. 2. See further in Syarif Nurhidayat and Arif Rusman Sutiana, "Pertanggungjawaban Pidana Korporasi pada Pembakaran Lahan Berdasarkan Teori Strict Liability", Undang: Jurnal Hukum, Vol. 1, No. 1, 2018, p. 43. 
Strict liability is a form of criminal responsibility for a criminal act committed without paying attention to the wrongdoing of perpetrator, also known as absolute liability, as long as there was a criminal act (actus reus). Strict liability is also known as liability without fault. Therefore, to hold the perpetrator accountable, it is sufficient to prove that the perpetrator has an allegation or knowledge of the consequences of actions. ${ }^{10}$ Thus, strict liability is a system of criminal liability that can be applied to a criminal act in which the perpetrator is a legal entity or corporation or an individual with a certain criminal act determined holding such responsibility. Criminal liability is based on the quality of the criminal act committed not on the quality of the fault. This is a deviation from the general principle of criminal responsibility, no crime without fault (geen straf zonder schuld).

The principle of criminal responsibility in general is based on based on the presence or absence of fault. There is no criminal responsibility if there is no fault. ${ }^{11}$ This absolute responsibility is adopted in the environmental law, Article 116 paragraph (1):

"(1) If an environmental crime is committed by, for, or on behalf of a business entity, the criminal charges and criminal sanctions are imposed on:

a. business entity; and/or

b. the person giving the order to commit the criminal act or the person acting as the leader of the activity in the criminal act.

(2) If the environmental crime as referred to in paragraph (1) is committed by a person, who is based on a work relationship or based on other relationships acting within the scope of work of a business entity, criminal sanctions shall be imposed on the person who gave the order or leader in the criminal act without regard to the act, the crime is committed individually or collectively."

The article mentions the responsibility of corporations committing criminal acts in the environmental sector. This is because corporations commit environmental crimes in order to gain profits. According to Wibisana, corporate accountability states that corporate responsibility and personal responsibility are needed in order to maintain accountability. ${ }^{12}$

\section{Conditions of Forest and Land Fires in Jambi Province and the Law Enforcement}

At the end of June 2020, the Government of Jambi Province had prepared to face forest and land fire. This is a quick response to the conditions in Batang Hari

Roeslan Saleh, op.cit., p. 23.

N.H.T Siahaan, Ekologi Pembangunan dan Hukum Tata Lingkungan, Jakarta: Erlangga, 1987, p. 46.

Andri Wibisana, "Kejahatan Lingkungan oleh Korporasi: Mencari Bentuk Pertanggungjawaban Korporasi dan Pemimpin/Pengurus Korporasi untuk Kejahatan Lingkungan di Indonesia?", Jurnal Hukum \& Pembangunan, Vol. 46, No. 2, 2016, p. 151. 
Regency and Tanjung Jabung Barat Regency, which are in a state of emergency forest and land fire alert. Jambi Province is included in the top six Provinces in Indonesia in the category of forest and land fire emergency along with five other provinces in Indonesia. The National Disaster Management Agency (BNPB) states that Jambi Province one of six provinces in Indonesia included in the category of forest fire emergency alert. The others are Riau, South Sumatra, West Kalimantan, Central Kalimantan and South Kalimantan. ${ }^{13}$ Furthermore, the data from the BNPB recorded that the area of forest and land covering 328,724 hectares. ${ }^{14}$ This condition resulted in the air quality index (AQI) in Jambi during 2019 hitting 390 and 335. The number is in the dangerous category. ${ }^{15}$ The highest air quality index that has occurred in Jambi is at 730, the most dangerous category in $2015 .^{16}$

Forest and land fires in Jambi Province are a serious problem. The forest fire incident in Jambi can be seen from the results of studies and analysis of Forest and Land Fires in 2019. According to some studies, the burned area covered 165.86.58 hectares, consisting of $114,900.2$ hectares the peat area and 50,286.38 acres nonpeat areas. ${ }^{17}$ Total state losses due to the burnings is estimated more than 17 trillion. This figure is almost four times the Jambi Province local budget of around Rp4.5 trillion. ${ }^{18}$ According to WALHI (Wahana Lingkungan Hidup - an environmental NGO), the losses caused by forest and land fires in Jambi Province reached Rp145 trillion. These losses include economic, environmental, and costrecovery losses.

The loss is based on the area of burned and damaged peatlands covering 114 thousand hectares. The damage to peatlands is spread across three regencies: Muarojambi, Tanjung Jabung Barat, and Tanjung Jabung Timur. ${ }^{19}$ The peat forest area that has burned is in a forest area with management permit/concession, either Forest Concession Rights $(\mathrm{HPH})$, concessions/industrial plantation forest

13 Juli Hantoro, "Sepanjang 2019, Kebakaran Hutan Dan Lahan Terjadi Di 28 Provinsi," https://nasional.tempo.co/read/1232980/sepanjang-2019-kebakaran-hutan-dan-lahan-terjadi-di-28-provinsi, accessed on September 2020.

14 Ekarina, "BNPB Catat 328.724 Hektare Hutan dan Lahan Terbakar hingga Agustus", https://katadata.co.id/berita/2019/09/20/bnpb-catat-328724-hektare-hutan-dan-lahan-terbakar-hinggaagustus, accessed on September 2020.

15 Ambaranie Nadia Kemala Movanita, "Selain Riau, Ini Provinsi dengan Kebakaran Hutan Parah Tahun 2019," https://nasional.kompas.com/read/2019/09/16/14103181/selain-riau-ini-provinsi-dengan-kebakaran-hutanparah-tahun-2019, accessed on May 2020.

16 Tribun News, "8 Fakta Mengerikan Dampak Kebakaran Hutan 2015 di Jambi", https://www.tribunnews.com/regional/2016/03/19/8-fakta-mengerikan-dampak-kebakaran-hutan2015-di-jambi?page=2, accessed on September 2020.

17 Detik News, "Aktivis Nilai Penegakan Hukum Pembakar Hutan di Jambi Tebang Pilih", https://news.detik.com/berita/d-4707982/aktivis-nilai-penegakan-hukum-pembakar-hutan-di-jambi-tebangpilih, accessed on February 2020.

18 Metro Jambi, "Kerugian Akibat Kerusakan Ekosistem di Jambi Mencapai 17 Triliun", https://www.metrojambi.com/read/2020/08/31/49711/kerugian-akibat-kerusakan-ekosistem-di-jambimencapai-17-triliun, accessed on July 2020.

19 Liputan 6, "Kerugian Akibat Kebakaran Hutan di Jambi Stara Rp145 Triliun", https://www.liputan6.com/regional/read/4117196/kerugian-akibat-kebakaran-hutan-di-jambi-setara-rp145triliun, accessed on July 2020. 
management rights ( $\mathrm{HTI})$, Peat Forest Protection (HLG) management rights, Palm Oil Plantation management rights (PKS), or National Park Management and individuals.

The condition of the forest and land burning disaster is so serious and has resulted in serious damage and loss. It requires strong law enforcement. Law enforcement on forest fires in Jambi has not provided a deterrent effect yet. There are forty-six companies acquiring fires in their concession land areas. Unfortunately, only four of them reached court proceedings and only two companies were declared guilty by the court. In addition, there are forty people declared suspects.

Law enforcement against forest and land burning cases is different from ordinary law enforcement because environmental law enforcement is enforced through various stages, starting from law enforcement in the administrative sector, in the field of civil law, and in the field of criminal law. These three areas of law enforcement are not carried out as an alternative but can be done together. This needs to be done considering that forest destruction has become an extraordinary crime because forest destruction has an extraordinary impact as in the part of the consideration of Law Number 18 of 2013 on the Prevention and Eradication of Forest Destruction. The law mentions that Forest destruction has become a crime with extraordinary, organized, and transnational impacts carried out with a sophisticated modus operandi. It has threatened the survival of the community so that in order to prevent and eradicate forest destruction effectively and to provide a deterrent effect, a strong legal foundation is needed and shall be able to guarantee the effectiveness of law enforcement".

Moreover, the Forestry Law also stated that the holders of forest-utilization concessions and parties receiving forest management authority are obliged to protect forests in their working areas. ${ }^{20}$ Acts as regulated in this article are punishable by serious imprisonment, namely a criminal sanction a maximum of ten years imprisonment and subject to a minimum fine of fifty billion Rupiahs. Specifically, for the act of burning forests according to Article 50 paragraph (3) d, every person is prohibited from burning forests since the act face criminal sanction of at least five years imprisonment and subject to a fine of maximum one and a half billion Rupiahs. ${ }^{21}$ Apart from the imposition of criminal sanctions, it does not preclude the possibility of stipulating other sanctions, either administrative sanctions or sanctions in the form of compensation payments.

Article 80:

"(1) Every act violating the law regulated in this law, without prejudice to the criminal sanction as provided for in Article 78, obliges the person responsible for the act to pay compensation according to

Article 49 of the Forestry Law.

Article 78 of the Forestry Law. 
The Implementation of the Strict-Liability Principle

to the Perpetrators of Forest and Land Burning

the level of damage or consequence caused to the State, for rehabilitation costs, restoration of forest conditions, or other necessary measures.

(2) Every holder of a business permit for area utilization, business permit for environmental service utilization, business permit for utilization of forest products, or permit for collecting forest products as regulated in this law, if violating provisions other than criminal provisions as provided for in Article 78 shall be subject to administrative sanctions."

The laws and regulations have determined every prohibited act and its sanctions in such a way. However, in terms of the law enforcement framework, only a few still very few companies holding concession permits that get sanctions. The Law of Environmental Protection and Management states clearly that Ministers, Governors, Regents and Mayors can apply administrative sanctions against companies that destroy environment. The administrative sanctions can take various forms, started from warning to revocation of license. This means that the Ministers, Governors, Regents, and Mayors are at the forefront of environmental law enforcement, especially regarding forest and land burning. Unfortunately, the enforcement of environmental laws against forest and land burners is still insignificant.

The condition of the recurring forest and land fire disasters with the result of the cross-border haze disaster is partly due to the weak enforcement of environmental criminal law in Indonesia, especially the Jambi Province. Environmental criminal law enforcement has not been carried out comprehensively and massively. Environmental criminal law enforcement is still at the stage as a shock effect for a moment. It has not been able to provide a long-term deterrent effect. This segmented enforcement has resulted in the presence of companies committing legal arson repeatedly. The companies do not carry out compliance with legal rules seriously. ${ }^{22}$

Article 88 of the Law of Environmental Protection and Management regulates the principle of strict liability. It clearly mentions that every person whose actions, business, and/or activities using hazardous and toxic materials, producing and/or managing waste of hazardous and toxic materials, and/or posing a serious threat to the environment, is absolutely responsible for the losses incurred as long as the loss is caused by the person concerned.

The Article shows that policy making has formulated the principle of strict liability, which is stated as "absolute responsibility" (loose translation from Indonesian "tanggung jawab langsung"). However, based on the article, strict

22 Deti Mega Purnamasari, “KLHK Akui Penegakan Hukum Pelaku Karhutla Baru Beri Efek Kejut, Belum Efek Jera”, Kompas, https://nasional.kompas.com/read/2019/10/01/18534971/klhk-akui-penegakan-hukum-pelakukarhutla-baru-beri-efek-kejut-belum-efek, accessed on September 2020. 
liability is applied only to compensation without the need to prove an element of fault. This strict liability is only applied to the civil domain and particularly in the case of a claim for compensation. Article 89 reads:

"(1) the expiration date to file a lawsuit in court follows the grace period as regulated in the provisions of the Civil Code and is calculated from the time it is known that environmental pollution and/or damage has been detected.

(2) Provisions regarding expiry date do not apply to environmental pollution and/or damage caused by businesses and/or activities that use and/or manage B3 and produce and/or manage hazardous waste."

The right to file a lawsuit for compensation is widely granted to the local government. In addition, there are the community's and the environmental organization's right to sue. Based on the Law, it can be seen that the right to claim compensation for environmental damage has been strictly regulated through the implementation of the principle of strict liability. Regarding the claim for compensation based on strict liability, there have been several district court decisions that have been strengthened by the decree of high court and the Supreme Court, for instance: the Bandung District Court Decision Number 49/Pdt.G/2003/PN.Bdg and the South Jakarta District Court Decision Number 456/Pdt.G-LH/2016/PN. Jkt.Sel. The decree declares that the lawsuit of the Minister of Environment and Forestry against PT. Waringin Agro Jaya has been accepted and the defendant must pay compensation up to Rp466 billion. ${ }^{23}$

In terms of criminal liability, Article 88 of the Law has become an interesting issue and a popular scientific discussion. The discussion mainly talks about on the implementation of the principle of strict liability for forest and land fire perpetrators. Currently, efforts have been made to expand enforcement through local governments. In this case, Regents and Mayors are expected to provide punishment with a deterrent effect. The regent or mayor as the licensing authority is authorized to impose administrative sanctions in the form of license revocation.

The fact is that the perpetrators of forest and land burning are companies with concessions. Then, for the sake of fairness, the principle of strict liability is also applied to all parties responsible for concessions as a form of responsibility of concessionaires for the land in their territory. The fact that environmental law enforcement, especially environmental criminal law against forest and land burning, especially against companies holding concession permits is still low. It is necessary to consider the implementation of the principle of strict liability in criminal law enforcement against forest and land burners because forest and land fires have

23 Normand Edwin Elnizar, "Strict Liability, Jurus Ampuh Hukum Lingkungan Menjerat Korposasi Tanpa Buktikan Unsur Kesalahan", https://www.hukumonline.com/berita/baca/lt5aa77cdf71ead/strictliability--jurus-ampuhhukum-lingkungan-menjerat-korporasi-tanpa-buktikan-unsur-kesalahan/, accessed on July 2020. 
fulfilled the requirements as an act that endangers the wider community. In addition, it has a global impact and is difficult to prove.

\section{Strict Liability in Law Enforcement against Forest and Land Fires}

The principle of strict liability can be examined through several approaches. Firstly, the approach can be through the material crime, namely criminal acts that refer to the consequences of an act where responsibility for an act committed by a person can be applied to the perpetrator if it is clear. The result of the action has materialized even though there is no element of guilt in the actor. This means that as long as forest and land fires have occurred, the perpetrators, both individuals and corporations, can be held accountable without the need to prove their mistakes. An assessment of the action is carried out by considering the consequences of the forest fire.

The consideration of the element of material fault is deemed to have been proven as long as the result of the act has occurred in the form of burning of forests and land in the company's concession area. The first approach shows that the implementation of the principle of immediate responsibility is an extension of criminal responsibility by excluding the principle of criminal liability without fault (geen straf zonder schuld). The principle of guilt can be excluded as long as the consequences of the act have been clearly proven. Based on this viewpoint, the companies holding concessions have been given the responsibility of protecting their respective areas.

Second, there is no extension of criminal liability in strict liability. In applying the principle of strict liability, the perpetrators are still concerned about the fault. The aspect of proving the perpetrator's guilt still pays attention to two main elements of criminal responsibility, namely the existence of an element of criminal action and an element of guilt. In the implementation of the principle of strict liability, the fault is considered to have existed if the result of a prohibited act has occurred. In this case, the result of an act in the form of forest and land fires has occurred. The prohibited effect is an absolute requirement for the implementation of the principle of strict liability to the act of burning forests and land. The criminal act of burning forest and land does not require intentional or negligent acts.

Based on Article 50 paragraph (3)(d) of the Forestry Law, "every person is prohibited from burning forests". ${ }^{24}$ The formulation of this article is a formal crime that is of "burning forest". In a formal crime, proof of guilt (mens rea) does not need to be proven. The perpetrator can be held accountable for the act he committed. In fact, according to Schwartzbach, prosecutors and judges do not need to prove whether the defendant committed the act due to negligence. ${ }^{25}$

\footnotetext{
Article 50 paragraph (3)(d) of the Forestry Law.

Micah Schwartzbach, op.cit.
} 
Several views on the reasons for the implementation of the principle of strict liability are based on the following points.

1. It is very significant that to obey important regulations aimed at social welfare.

2. Evidence by proving the perpetrator's mens rea will be very difficult in relation to actions that have an impact on social welfare.

3. The high level of social danger is caused by concerned action. ${ }^{26}$

The arousing question is on whether the implementation of strict liability also covers individual perpetrators or only to corporate actors. Several theories state that in order to be accountable for an act to an individual, the individual must meet several conditions as follows.

1. The occurrence of acts that are contrary to the law.

2. The act can be blamed on the perpetrator for a fault.

3. Perpetrators of criminal acts are people who can be held accountable for their actions. $^{27}$

Therefore, in a criminal event, these three conditions need to be seen. If the perpetrator of the criminal act has no fault and there are excuses for forgiveness and reasons for not being able to take responsibility for the action, the perpetrator cannot be held accountable even though the actions breaking the law. Based on this view, individual perpetrators of forest and land fires, of course, should face general provisions of criminal liability based on "geen straf zonder schuld" (no crime without fault). The perpetrator can be declared convicted based on the ability to take responsibility for actions (Toerekeningsvatbaarheid). ${ }^{28}$

Criminal liability of criminal actor, in general, always required an element of fault. The element of fault is inner attitude that exists in criminal actor. However, it can still be considered if the act fulfills the criteria regarding social impact resulting from the act. On the other hand, before analyzing whether company/corporation is a forest burner, criminal responsibility needs to be examined first and also to pay attention to whether the act qualifies as a corporate crime. There is a sufficiently large quantity of crimes committed by corporations that are directly related to the public interest. It can be economical, social, physical, and environmental.

"corporate crime is any criminal offense committed by and hence chargeable to a corporation because of the activities of its officers or employees (e.g., price fixing, toxic waste dumping), often referred to as white collar crime."

\footnotetext{
26 Bayu Haritia dan Hartiwiningsih, "Penerapan Asas Strict Liability dalam Kebakaran Hutan dan Lahan yang Dilakukan oleh Korporasi", Recidive, Vol. 8, No. 2, 2019, p. 119.

27 E. Utrecht, Hukum Pidana 1, Jakarta: PT Penerbitan Universitas, 1994, pp. 153-251. See further JM van Bemmelen, Hukum Pidana 1 (Ons Straftrecht I), Jakarta: Binacipta, 1987, p. 99. See further Wirjono Prodjodikoro, Asas-Asas Hukum Pidana di Indonesia, Bandung: Eresco, 1989.

28 EY Kanter and R Sianturi, Asas-asas Hukum Pidana di Indonesia dan Penerapannya, Jakarta: Storia Grafika, 2002, p. 250.
} 
Furthermore, according to Brainwith, there are three main ideas of corporate crime distinguishing it from individual crime. First, the act is contrary to the law committed by corporations and the people in them from the perspective of administrative procedures. Corporate crime act is not only about acts that violate law or criminal law but also contains other legal aspects such as actions that are contrary to the law in the field of civil law and acts that violate aspects of administrative law. Second, corporations are legal subjects through the people in them or their managers or representatives. They can be seen as perpetrators of criminal acts/acts (as a criminal), where later in the practice of judicial justice is still very much dependent on the form of crime that was committed, how the rules were violated or depending on the ability to prove and prosecute the case. Third, based on the aspect of motivation, it is also assessed whether the motivation in committing a crime is solely for the benefit of the corporation and not for personal gain. The purpose of the criminal act committed is aimed at meeting the needs and performance/achievement of organizational goals and in carrying out the act. It is also possible to support the internal operational rules of the corporation as a subculture of the organization. ${ }^{29}$

Based on the definition, criminal responsibility of corporations as perpetrators of forest and land fires needs to pay attention to whether these acts meet the criteria as corporate crimes. It is considered so when the act of burning the forest and land is the policy of the company leadership in order to fulfill the company's profits.

Corporate crime is not a direct crime committed by a corporation physically, instead, a corporation as a legal entity can only act through its management. The management's actions that are agreed upon as company actions can be viewed as legal acts of the company. Therefore, corporate action against forest and land fires can only be viewed as a crime when it meets one of the following conditions.

1. It can be clearly proven that forest and land fires in the concession area are the acts of the management or employees or employees of the company. If it can be proven otherwise that the forest and land fires were caused by certain people/individuals who cannot be proven to have a relationship with their corporations, then the forest and land fires are not the accountability of corporation/company holding the concession.

2. It is necessary to pay attention to whether the burning of forest and land is a company policy in order to achieve the profit goals of the corporation/concession holder.

Article 49 of the Forestry Law states that "holders of rights or permits are responsible for forest fires in their working areas". It can be interpreted as that, 
"a corporation as a right or permit holder is responsible for the occurrence of forest fires in its working area, as long as the forest fires are caused by the actions of people acting for and on behalf of the corporation, based on work relations or other relationships, in order to achieve the corporate goals to benefit the corporation."

Theoretically, act and fault are two separate domains of proof. However, perpetrator who is proven to have committed an act does not necessarily have a fault and can be held accountable. Unfortunately, in the criminal act of land and forest burning, the two domains can be proven at once automatically. In the case of forest and land burning, the fault is automatically proven by the act of burning. The corporation has been held accountable for the act of burning forest and land as long as it is sufficiently proven that forest and land fires have actually occurred.

Strict liability in the enforcement of environmental criminal law does not result in excessive responsibility for the perpetrators of forest fire crime by taking into account the following conditions.

1. The act of burning the forest is an act that is against the law which is very strong (unlawful) and is very contrary to the principle of prudence and propriety, which the consequences should be predictable.

2. The act of burning the forest is a very anti-social act that has the effect of endangering social and economic life.

3. The act of burning the forest causes serious environmental damage in the form of ecosystem damage.

4. The act of burning the law is an act that endangers public health, safety, and public morals (a particular activity potential danger of public health, safety, or moral).

5. Forest burning results in national disasters and transnational disasters, namely transboundary haze pollution.

So, based on this, it is fitting that the accountability of forest burners in Indonesia is based on strict liability. The principle of strict liability is in line with the precautionary principle derived from the Principles of the Rio Declaration:

"To protect the environment, this precautionary principle must be applied in every country according to the capability of the country concerned. If there is a threat of serious or irreversible damage, the absence of scientific evidence cannot be used as an excuse to postpone efforts to prevent environmental degradation". ${ }^{30}$ 
This precautionary principle shows that the implementation of the principle of strict liability in the crime of forests and land burning is expected to function as an effort to prevent forest and land fires. The Supreme Court Regulation states that in determining criminal responsibility, two important things are needed: (1) negligence, and (2) strict liability. In terms of strict liability, people who cause environmental damage are responsible for providing compensation for the damage it causes. In terms of strict liability, the perpetrator still has to be responsible in terms of compensation even though the perpetrator has applied the precautionary principle. It is expected that the implementation of the principle of strict liability will have the power of law enforcement through the implementation of sanctions with deterrent effect. It is also expected that the combination of criminal liability and compensation can be a preventive effort in cases of forest and land fires. Forest and land fires are mostly located in concession areas, including Forest Concession Rights (HPH), Industrial Plantation Forests (HTI), Peat Protected Forests (HLG), Oil Palm Plantation (PKS), National Parks, and community lands. The area of burned land covered 3,499 hectares of industrial plantation forests (HTI), 4,359 hectares of oil palm plantations, 1,193 hectares of forest management rights (HPH) areas, 6,579 hectares of restoration areas, and 2,954 hectares of community land.

Progressive environmental law enforcement is needed in the context of tackling forest and land fires. Helmi et.al mention that in the process taken within the framework of resolving the problem of forest and land fire crimes, various conditions are needed to support related parties to care and be enthusiastic to resolve forest and land fires. The conditions for the various parties involved in cases of forest and land fires will encourage judges in the settlement of this case to be able to apply non-conventional law enforcement. ${ }^{31}$ This progressive law enforcement is a form of law enforcement that allows the goal of restoring environmental damage caused by forest and land fires to be restored in addition to the perpetrators of burning forests and forest areas to receive criminal sanctions as a form of criminal responsibility for the actions that have been committed.

In the future, there is a need for an inventory of laws and regulations related to forest burning to formulate accountability based on strict liability in the enforcement of criminal law in Indonesia. Criminal responsibility based on strict liability to perpetrators of forest burning is expected to be able to realize justice and is expected to be a powerful tool in deterring the perpetrators and preventing transnational haze disasters, extensive environmental and ecosystem damage, and their impacts on community economic activities. In addition, Indonesia has the largest forest area in the ASEAN region and is a country that has ratified the ASEAN Regional Agreement on Transboundary Haze Pollution (AATHP). 31 Helmi (et.al), “Documenting Land-Combustion and Progressive Law Enforcement in Indonesia”, Library
Philosophy and Practice, 2019, p. 2, https://digitalcommons.unl.edu/libphilprac/2657/. 
Based on the urgency of the principle of strict liability in this criminal responsibility, future criminal law policies based on this. Criminal responsibility without fault has been formulated in the Draft of Criminal Code. Article 37 of the Draft of Criminal Code regulates the concept of strict liability as an exception to the principle of fault. $^{32}$

"Criminal liability is a condition for the fulfillment of objective reproaches and subjective reproaches to convict someone who has committed a criminal act".

The regulation on criminal liability based on "fault" is provided in Article 38, which stipulates that no one who commits a criminal act can be held accountable without any fault. ${ }^{33}$ The mistakes in question are the ability to be responsible, mistakes, or negligence and the absence of excuses. However, the draft provides an opportunity for certain criminal acts to be subject to criminal liability without fault/immediate accountability. It even stipulates responsibility for criminal acts committed by other people in Article 39 as follows. ${ }^{34}$

"(1) For certain criminal acts, the law may determine that a person can be convicted solely because the elements of the criminal act have been fulfilled without regard to any wrongdoing.

(2) If determined by law, every person can be held accountable for a criminal act committed by another person".

Certain criminal acts as regulated in the draft still need further elaboration. Then, the principle of strict liability is not used carelessly. This further regulation specifically concerns the criteria for certain criminal acts, which violate the general principle of "geen straf zonder schuld" where criminal responsibility is based on whether or not the perpetrator is guilty. This criterion becomes important if there is no concern that excessive use of the principle of strict liability will occur. With the words "certain criminal acts" have not been further elaborated, it can be interpreted that various actions can be accounted for as long as an act has been fulfilled through the fulfillment of the elements. The view on the principle of strict liability in the Draft of Criminal Code is an exception from the view that the strict separation of criminal acts and criminal liability means that the perpetrator of a criminal act can be convicted not only because of an actus reus, but also because of a fault. The exclusion of criminal liability based on fault in the draft is a policy for future reform of criminal liability.

\footnotetext{
Article 37 of the Draft of Criminal Code.

Article 38 of the Draft of Criminal Code.

Article 39 of the Draft of Criminal Code.
} 


\section{E. Conclusion}

The principle of strict liability in the law enforcement against perpetrators of forest and land burnings can be applied to corporate actors based on some conditions. They are, among others, that the act of burning forests and land must fulfill the elements of a corporate crime. For individual perpetrators of forests and land burnings, the principle of non-punishment is still used without fault (geen straf zonder schuld). The implementation of the principle of strict liability to perpetrators of forest and land fires is in line with the "precautionary principle". In the implementation of the precautionary principle in criminal liability for environmental crimes, there are (1) negligence and (2) strict liability.

The future criminal law policy in the Draft of Criminal Code is based on Article 39 paragraph (1) which allows strict liability to be applied in certain criminal acts. The crime of forest and land burnings is a crime that in the future can be determined as a certain crime. Therefore, strict liability can be applied to perpetrators of forest and land burnings, both individual and corporate actors.

\section{References}

\section{Books}

Bemmelen, J.M. van, Hukum Pidana 1 (Ons Straftrecht I), Binacipta, Jakarta, 1987.

E.Y. Kanter and R Sianturi, Asas-asas Hukum Pidana di Indonesia dan Penerapannya, Storia Grafika, Jakarta, 2002.

Moeljatno, Perbuatan Pidana dan Pertanggungjawaban dalam Hukum Pidana, Bina Aksara, Jakarta, 1985.

N.H.T. Siahaan, Ekologi Pembangunan dan Hukum Tata Lingkungan, Erlangga, Jakarta, 1987.

Peter Mahmud Marzuki, Penelitian Hukum, Kencana Prenada Media Group, Jakarta, 2010.

Roeslan Saleh, Pikiran-Pikiran tentang Pertanggungjawaban Pidana, Ghalia Indonesia, Jakarta, 1982.

Utrecht, E., Hukum Pidana 1, PT Penerbitan Universitas, Jakarta, 1994.

Wirjono Prodjodikoro, Asas-Asas Hukum Pidana di Indonesia, Eresco, Bandung, 1989.

\section{Other Documents}

Ambaranie Nadia Kemala Movanita, "Selain Riau, Ini Provinsi dengan Kebakaran Hutan Parah Tahun 2019," Kompas, https://nasional.kompas.com/read/2019/09/16/14103181/selain-riau-iniprovinsi-dengan-kebakaran-hutan-parah-tahun-2019, accessed on May 2020.

Andri Wibisana, "Kejahatan Lingkungan oleh Korporasi: Mencari Bentuk Pertanggungjawaban Korporasi dan Pemimpin/Pengurus Korporasi untuk Kejahatan Lingkungan di Indonesia?", Jurnal Hukum \& Pembangunan, Vol. 46, No. 2, 2016. 
Bayu Haritia and Hartiwiningsih, "Penerapan Asas Strict Liability dalam Kebakaran Hutan dan Lahan yang Dilakukan oleh Korporasi", Recidive, Vol. 8, No. 2, 2019.

Deti Mega Purnamasari, "KLHK Akui Penegakan Hukum Pelaku Karhutla Baru Beri Efek Kejut, Belum Efek Jera", https://nasional.kompas.com/read/2019/10/01/18534971/klhk-akui-penegakanhukum-pelaku-karhutla-baru-beri-efek-kejut-belum-efek, accessed on September 2020.

Detik News, "Aktivis Nilai Penegakan Hukum Pembakar Hutan di Jambi Tebang Pilih", https://news.detik.com/berita/d-4707982/aktivis-nilai-penegakanhukum-pembakar-hutan-di-jambi-tebang-pilih, accessed on February, 2020.

Detik News, "Aktivis Nilai Penegakan Hukum Pembakar Hutan di Jambi Tebang Pilih", $\quad$ https://news.detik.com/berita/d-4707982/aktivis-nilai-penegakanhukum-pembakar-hutan-di-jambi-tebang-pilih, accessed on February, 2020.

Ekarina, "BNPB Catat 328.724 Hektare Hutan dan Lahan Terbakar hingga Agustus", https://katadata.co.id/berita/2019/09/20/bnpb-catat-328724-hektare-hutandan-lahan-terbakar-hingga-agustus, accessed on September 2020.

Glauber (et.al), “Laporan Pengetahuan Lanskap Berkelanjutan Indonesia: Kerugian dari Kebakaran Hutan \& Analisa Dampak Ekonomi dari Krisis Kebakaran Tahun 2015", The World Bank, 2016.

Helmi (et.al), "Documenting Land-Combustion and Progressive Law Enforcement in Indonesia", Library Philosophy and Practice, 2019, https://digitalcommons.unl.edu/libphilprac/2657/.

Juli Hantoro, "Sepanjang 2019, Kebakaran Hutan Dan Lahan Terjadi Di 28 Provinsi," Tempo, https://nasional.tempo.co/read/1232980/sepanjang-2019-kebakaranhutan-dan-lahan-terjadi-di-28-provinsi, accessed on September 2020.

Liputan 6, "Kerugian Akibat Kebakaran Hutan di Jambi Stara Rp145 Triliun", https://www.liputan6.com/regional/read/4117196/kerugian-akibat-kebakaranhutan-di-jambi-setara-rp145-triliun, accessed on July 2020.

Metro Jambi, "Kerugian Akibat Kerusakan Ekosistem di Jambi Mencapai 17 Triliun", https://www.metrojambi.com/read/2020/08/31/49711/kerugian-akibatkerusakan-ekosistem-di-jambi-mencapai-17-triliun, accessed on July 2020.

Normand Edwin Elnizar, "Strict Liability, Jurus Ampuh Hukum Lingkungan Menjerat Korposasi Tanpa Buktikan Unsur Kesalahan", Hukumonline, https://www.hukumonline.com/berita/baca/lt5aa77cdf71ead/strictliability-jurus-ampuh-hukum-lingkungan-menjerat-korporasi-tanpa-buktikan-unsurkesalahan/, accessed on July 2020.

Schwartzbach, Micah, "Is There "Strict Liability" in Criminal Law?", https://www.nolo.com/legal-encyclopedia/is-strict-liability-criminal-law.html, accessed on June 2020.

Syarif Nurhidayat and Arif Rusman Sutiana, "Pertanggungjawaban Pidana Korporasi pada Pembakaran Lahan Berdasarkan Teori Strict Liability", Undang: Jurnal Hukum, Vol. 1, No. 1, 2018. 
Tribun News, "8 Fakta Mengerikan Dampak Kebakaran Hutan 2015 di Jambi", https://www.tribunnews.com/regional/2016/03/19/8-fakta-mengerikan-dampakkebakaran-hutan-2015-di-jambi?page=2, accessed on September 2020.

\section{Legal Documents}

Draft of Criminal Code of Indonesia.

Law Number 41 of 1999 on Forestry [Undang-Undang Republik Indonesia Nomor 41 Tahun 1999 tentang Kehutanan].

Law Number 32 of 2009 on Environmental Protection and Management [UndangUndang Republik Indonesia Nomor 32 Tahun 2009 tentang Perlindungan dan Pengelolaan Lingkungan Hidup].

Law Number 18 of 2013 on Anticipation, Prevention, and Eradication of Forest Destruction [Undang-Undang Republik Indonesia Nomor 18 Tahun 2013 tentang Pencegahan dan Pencegahan dan Pemberantasan Perusakan Hutan].

Decree of the Supreme Court of the Republic of Indonesia Number 36/KMA/SK/II/2013 on Enforcement of Guidelines for the Management of Environmental Cases [Keputusan Mahkamah Agung Republik Indonesia Nomor: 36/KMA/SK/II/2013 tentang Pemberlakuan Pedoman Penanganan Perkara Lingkungan Hidup]. 